\title{
ESTIMATION OF EMISSIONS OF AIR POLLUTANTS IN THE KRAPINA-ZAGORJE COUNTY
}

\author{
Božica Šorgič , Vladimir Kušan*, Igor Tošič ${ }^{* *}$, Bojana Borić”, Hrvoje Pandža ${ }^{* * *}$ \\ * Oikon Ltd. - Institute for Applied Ecology, Zagreb, Croatia \\ ${ }^{* *}$ Croatian Waters Ltd., Water Management Department for \\ Mura and Upper Drava Rivers, Varaždin, Croatia \\ DLS, Ltd., Rijeka, Croatia
}

corresponding author: Božica Šorgić, e-mail: bsorgic@oikon.hr

\section{ABSTRACT}

The Program for the protection of air quality, ozone layer, climate change mitigation and adaptation of the Krapina-Zagorje County is prepared in accordance with the Article 12 of the Air Protection Act (OG 130/11, 47/14, 61/17, 118/18). The Program sets targets and measures by priority sectors, deadlines and responsible authorities for measures implementation over a five-year period in the County. For the purpose of defining protection measures, based on available data, estimation of annual emissions of pollutants into air was performed: nitrogen oxides, carbon monoxide, sulphur oxides, particles, volatile organic compounds, ammonia, carbon dioxide, methane and dinitrogen monoxide from the main sectors. Emissions were estimated using the EMEP/EEA methodology and 2006 IPCC Guidelines for National Greenhouse Gas Inventories methodology. Road traffic emissions were estimated using DEFRA/DECC methodology.

Based on the results on estimated pollutant emissions in the County, appropriate measures have been defined for the protection and improvement of air quality.

Keywords: estimation of pollutants emission, air quality, Krapina-Zagorje County

\section{INTRODUCTION}

The Program for protection of air quality, ozone layer, climate change mitigation and climate change adaptation of the KrapinaZagorje County (hereinafter referred to as the Air Protection Program) is prepared in accordance with Article 12 of the Air Protection Act [1].
The Air Protection Program defines targets and measures by priority sectors, deadlines and responsible bodies for measures implementation with the main purpose of protecting and improving air quality, ozone layer and mitigation of climatic changes in the Krapina-Zagorje County area over a five-year period.

The program contains in particular: 
- Principles and benchmarks for determining goals and priorities,

- Assessment of air quality,

- Priority measures and activities,

- Prevention measures for the protection of air quality,

- Short-term measures, where there is a risk of exceeding the warning threshold,

- Measures to achieve limit values (LV) for certain pollutants in the air within a given time limit if exceeded,

- Measures to reduce emissions of pollutants and greenhouse gases,

- Measures to meet the greenhouse gas emission limitation obligations for greenhouse gas emissions not covered by the Emission Trading System,

- Measures to deal with substances that damage the ozone layer and reduce the emissions of fluorinated greenhouse gases,

- Measures to reduce emissions of persistent organic pollutants and heavy metals,

- Measures to encourage the increase of energy efficiency and use of renewable energy,

- Measures to reduce total emissions from traffic,

- Adaptation measures to climate change,

- The way of implementing measures,

- Sequence of measures,

- Deadline for execution of measures,

- Competent responsible body,

- Evaluation of the resources for the implementation of the Program and the order of use of the funds according to the identified priority measures and activities in the Program.

In order to determine the objectives, measures and priorities of air protection within the Air Protection Program, based on the available data, the estimation of pollutant emissions into the air from different stationary and diffuse sources in the Krapina-Zagorje County was made. This paper presents data on estimated emissions of pollutants.

\section{METHODOLOGY}

The assessment included the emissions of the following pollutants into the air: nitrogen oxides, carbon monoxide, sulphur oxides, particles, volatile organic compounds (VOC) and ammonia and greenhouse gases: carbon dioxide, methane and dinitrogen monoxide. The main sectors included in the estimation are: Energy (combustion of fuels in industry, service sector, households and construction, traffic (road traffic), Industry (volatile organic compounds), Agriculture and Waste. Given the limited availability of data and for comparing the trend, years 2011 and 2015 were used as the reference years.

Nitrogen oxides (NOx), carbon monoxide (CO), sulphur oxides ( $\mathrm{SOx}$ ), $\mathrm{PM}_{10}$ particles, ammonia $\left(\mathrm{NH}_{3}\right)$ and volatile organic compounds (VOC) emissions from the combustion in the industry, service sector, households and construction sector in the County were estimated based on data on energy consumption and emission factors for different fuels using the EMEP/EEA methodology. Fuel Consumption Data from the Energy Efficiency Program for Energy Consumption of Krapina-Zagorje County 2014 - 2016 were used [2].

Since the total emissions were calculated irrespective of the type of industry and that most of them use smaller-scale combustion units and installations, the Tier 1 approach of EMEP/EEA air pollutant emission inventory guidebook 2016 (1.A.4 Small Combustion, Chapter 3.2, Tables 3.8. - 3.10.) [3] was used for the industry, service and construction sector. Tier 2 approach has been used for the calculation of emissions from households (1.A.4 Small Combustion, Chapter 3.3, Tables 3.17 - 3.20) [3].

The estimation of greenhouse gas emissions: carbon dioxide $\left(\mathrm{CO}_{2}\right)$, methane $\left(\mathrm{CH}_{4}\right)$ and dinitrogen monoxide $\left(\mathrm{N}_{2} \mathrm{O}\right)$ was based on the emission factors given in the 2006 IPCC Guidelines for National Greenhouse Gas Inventories (Vol. 2 Energy, Chapter 2 Stationary Combustion, Tables 2.3 - 2.5) [4]. 
Data on volatile organic compounds emissions from activities involving organic solvents or products containing volatile organic compounds were used from the "Volatile Organic Compound Emission Data" database [5].

Emissions of pollutants from agriculture were calculated on the basis of data on amounts of mineral fertilizers decomposed into agricultural areas according to the first level methodology (Tier 1) of EMEP/EEA emission inventory guidebook 2016, 3D crop production and agricultural soils (Chapter 3.3.2.) [3] and according to the 2006 Methodology of IPCC Guidelines for National Greenhouse Gas Inventories: $\mathrm{N}_{2} \mathrm{O}$ Emissions from Managed Soils and $\mathrm{CO}_{2}$ Emissions from Lime and Urea Application (Chapter 11) [4]. Cattle breeding data were not available.

Emissions from waste and waste water were estimated based on data on waste disposed at all landfills in the Krapina-Zagorje County (Landfills: Gorjak, Gubaševo, Lesičak, Medvedov jarek, Hum na Sutli and Tugonica), the number of inhabitants and the quantity of waste water discharged in the Krapina-Zagorje County according to the first level methodology (Tier 1) EMEP/EEA emission inventory guidebook 2016, 5.A Biological treatment of waste - Solid waste disposal on land (Table 3-1) and 5.D Wastewater handling (Table 3-1) [3]. Emissions of greenhouse gases from waste were estimated according to the simple methodology of the EIB European Investment Bank Induced GHG Footprint, Methodologies for the Evaluation of Project GHG Emissions and Emission Variations, Version 10.1, 2014 [6]. Emissions of greenhouse gases from waste waters have been estimated using 2006 Methodology IPCC Guidelines for National Greenhouse Gas Inventories and national emission factors given in the Greenhouse Gas Inventory Report for the Republic of Croatia for the period 1990 - 2014, NIR 2016 [7].

The calculation of annual emissions from road traffic were based on data on the number of vehicles in the Krapina-Zagorje County, the average travelled distance and fuel consumption using the first level methodology (Tier 1) EMEP/EEA 1.A.3.bi-iv Road Transport 2016 [3]. For calculation of emissions of greenhouse gases DEFRA/DECC (Department for Environmental, Food \& Rural Affairs/Department of Energy \& Climate Change) methodology, and the DCF 2015 (DEFRA Carbon Factors) were used [8].

\section{RESULTS}

\section{Stationary sources}

\section{Fuel combustion emissions}

Estimated emissions of pollutants from fuel combustion in the industry and general consumption sector (households, service sector and construction sector) for years 2011 and 2015 are shown in the Table 1.

\section{Emissions of volatile organic compounds}

According to Art. 64 of the Regulations on emission limit values for air emissions from stationary sources [9], installations in which one or more activities involving organic solvents are carried out are obliged to report the data on volatile organic compounds emissions into the EHOS database. Emissions of volatile organic compounds in the KrapinaZagorje County are shown in Table 2.

\section{Diffuse sources}

Diffuse sources of pollutants are sources in which pollutants are introduced into the air without a specific discharge / chimney (devices. certain activities. surfaces and other places).

Diffuse sources in the Krapina-Zagorje County include emissions from waste (waste water and waste disposal), agriculture (application of mineral fertilizers to agricultural areas and cattle breeding), fugitive emissions from fuels 
and emissions from exploitation fields for extracting mineral raw materials. Given the availability of data, only emissions from waste and waste waters and the application of fertilizers to agricultural land are estimated.

Table 1. Estimated emissions of air pollutants from combustion in industry sector and general sector in the Krapina-Zagorje County

\begin{tabular}{|c|c|c|c|c|c|c|c|c|c|}
\hline Fuel & $\mathrm{NO}_{\mathrm{x}}$ & $\mathrm{SO}_{\mathrm{x}}$ & $\mathrm{CO}$ & VOC & $\mathrm{PM}_{10}$ & $\mathrm{CO}_{2}$ & $\mathrm{CH}_{4}$ & $\mathrm{~N}_{2} \mathrm{O}$ & $\mathrm{NH}_{3}$ \\
\hline \multicolumn{10}{|c|}{ t/year } \\
\hline \multicolumn{10}{|c|}{ Industry } \\
\hline Natural gas & 178.34 & 1.61 & 69.89 & 55.43 & 1.88 & 135.201 .00 & 2.4100 & 0.2410 & \\
\hline Liquid fuel & 11.82 & 0.92 & 1.57 & 0.50 & 0.45 & 2.889 .90 & 0.1170 & 0.0234 & \\
\hline Diesel & 1.82 & 0.14 & 0.24 & 0.08 & 0.07 & 444.60 & 0.0180 & 0.0036 & \\
\hline Biomass & 3.91 & 0.47 & 24.51 & 12.90 & 6.15 & 4.816 .00 & 1.2900 & 0.1720 & 1.59 \\
\hline 2011 & 195.89 & 3.15 & 96.21 & 68.91 & 8.55 & 143.351 .50 & 3.84 & 0.44 & 1.59 \\
\hline Natural gas & 194.03 & 1.76 & 76.04 & 60.31 & 2.05 & 147.094 .20 & 2.6220 & 0.2622 & \\
\hline Liquid fuel & 12.42 & 0.97 & 1.65 & 0.53 & 0.48 & 3.038 .10 & 0.1230 & 0.0246 & \\
\hline Diesel & 1.82 & 0.14 & 0.24 & 0.08 & 0.07 & 444.60 & 0.0180 & 0.0036 & \\
\hline Biomass & 4.64 & 0.56 & 29.07 & 15.30 & 7.29 & 5712.00 & 1.5300 & 0.2040 & 1.89 \\
\hline 2015 & 212.91 & 3.43 & 107.00 & 76.21 & 9.88 & 156.288 .90 & 4.29 & 0.49 & 1.89 \\
\hline \multicolumn{10}{|c|}{ General Consumption Sector } \\
\hline \multicolumn{10}{|c|}{ Households } \\
\hline Fuel & $\mathrm{NO}_{\mathrm{x}}$ & $\mathrm{SO}_{\mathrm{x}}$ & $\mathrm{CO}$ & VOC & $\mathrm{PM}_{10}$ & $\mathrm{CO}_{2}$ & $\mathrm{CH}_{4}$ & $\mathrm{~N}_{2} \mathrm{O}$ & $\mathrm{NH}_{3}$ \\
\hline Natural gas & 43.39 & 0.31 & 22.73 & 1.86 & 0.21 & 57951.30 & 5.165 & 0.1033 & 0.0 \\
\hline Biomass & 34.50 & 7.59 & 2760.00 & 414.00 & 524.40 & 77280.00 & 207.00 & 2.7600 & 48.30 \\
\hline 2011 & 77.89 & 7.90 & 2782.73 & 415.86 & 524.61 & 135231.30 & 212.17 & 2.86 & 48.30 \\
\hline Natural gas & 48.59 & 0.35 & 25.45 & 2.08 & 64907.70 & 0.23 & 5.785 & 0.1157 & 0.0 \\
\hline Biomass & 37.80 & 8.32 & 3024.00 & 453.60 & 84672.00 & 574.56 & 226.80 & 3.024 & 52.92 \\
\hline 2015 & 86.39 & 8.66 & 3049.45 & 455.68 & 149579.70 & 574.79 & 232.59 & 3.14 & 52.92 \\
\hline \multicolumn{10}{|c|}{ Service Sector } \\
\hline Fuel & $\mathrm{NO}_{\mathrm{x}}$ & $\mathrm{SO}_{\mathrm{x}}$ & $\mathrm{CO}$ & VOC & $\mathrm{PM}_{10}$ & $\mathrm{CO}_{2}$ & $\mathrm{CH}_{4}$ & $\mathrm{~N}_{2} \mathrm{O}$ & $\mathrm{NH}_{3}$ \\
\hline Natural gas & 33.00 & 0.30 & 12.93 & 10.26 & 0.35 & 25020.60 & 2.23 & 0.0446 & \\
\hline Liquid fuel & 9.40 & 0.73 & 1.25 & 0.78 & 0.36 & 2297.10 & 0.31 & 0.0186 & \\
\hline 2011 & 42.41 & 1.03 & 14.18 & 11.03 & 0.71 & 27317.70 & 2.54 & 0.06 & 0.0 \\
\hline Natural gas & 36.33 & 0.33 & 14.24 & 11.29 & 0.38 & 27545.10 & 2.455 & 0.0491 & \\
\hline Liquid fuel & 5.16 & 0.40 & 0.69 & 0.43 & 0.20 & 1259.70 & 0.17 & 0.0102 & \\
\hline Biomass & 1.27 & 0.15 & 7.98 & 4.20 & 2.00 & 1568.00 & 4.20 & 0.0560 & 0.52 \\
\hline 2015 & 42.76 & 0.89 & 22.90 & 15.92 & 2.58 & 30.372 .80 & 6.83 & 0.12 & 0.52 \\
\hline \multicolumn{10}{|c|}{ Construction } \\
\hline Fuel & $\mathrm{NO}_{\mathrm{x}}$ & $\mathrm{SO}_{\mathrm{x}}$ & $\mathrm{CO}$ & VOC & $\mathrm{PM}_{10}$ & $\mathrm{CO}_{2}$ & $\mathrm{CH}_{4}$ & $\mathrm{~N}_{2} \mathrm{O}$ & $\mathrm{NH}_{3}$ \\
\hline Liquid fuel & 0.61 & 0.05 & 0.08 & 0.03 & 0.02 & 148.20 & 0.0060 & 0.0012 & \\
\hline LNG & 7.00 & 0.04 & 1.75 & 0.35 & 0.35 & 11550.0 & 0.05 & 0.02 & \\
\hline 2011 & 7.61 & 0.09 & 1.83 & 0.38 & 0.37 & 11698.20 & 0.06 & 0.02 & \\
\hline Liquid fuel & 0.61 & 0.05 & 0.08 & 0.03 & 0.02 & 148.20 & 0.0060 & 0.0012 & \\
\hline LNG & 7.80 & 0.04 & 1.95 & 0.39 & 0.39 & 12870.00 & 0.0585 & 0.0195 & \\
\hline 2015 & 8.41 & 0.09 & 2.03 & 0.42 & 0.41 & 13018.20 & 0.0645 & 0.0207 & \\
\hline
\end{tabular}


Table 2. Total emissions of volatile organic compounds (VOC) in the Krapina-Zagorje County

\begin{tabular}{|c|c|}
\hline \multirow{2}{*}{ Year } & VOC \\
\cline { 2 - 2 } & t/year \\
\hline 2011 & 2931.79 \\
\hline 2015 & 10.77 \\
\hline
\end{tabular}

Estimated emissions from agriculture (application of fertilizer on farmland) and waste are shown in the Tables 3 and 4 . Given that data on fertilizer use on soil were not available for 2011, it was roughly assumed that the quantities in 2011 and 2012 have not changed significantly and that emissions in 2012 were the same as in 2011.

Table 3. Estimated emissions from fertilizer application to land in the Krapina-Zagorje County in 2011 and 2015

\begin{tabular}{|c|c|c|c|c|}
\hline \multirow{2}{*}{} & \multicolumn{4}{|c|}{$\mathrm{t} / \mathrm{year}$} \\
\cline { 2 - 5 } & $\mathrm{VOC}$ & $\mathrm{NH}_{3}$ & $\mathrm{NO}$ & $\mathrm{N}_{2} \mathrm{O}$ \\
\hline 2011 & 50.29 & 545.50 & 436.40 & 109.1 \\
\hline 2015 & 61.23 & 496.40 & 397.12 & 99.28 \\
\hline
\end{tabular}

Emissions from waste and waste water were estimated based on data on waste disposed at landfills in the Krapina-Zagorje County: Gorjak, Gubaševo, Lesičak, Medvedov jarek, Hum na Sutli and Tugonica according to the data from the Municipal Waste Reports [10, 11], population [12] and the amount of waste water discharged in the Krapina-Zagorje County area in the considered years [13].

Estimation of annual emissions from mobile sources, primarily road traffic, was based on following data: data on the number of registered vehicles of the Krapina-Zagorje County [14] for the following categories: passenger cars, light vehicles (LV), heavy duty vehicles (HV) and motorcycles; data on the average annual journey per vehicle on the territory of the Republic of Croatia [15, 16] and the average fuel consumption by vehicle type (Table 5) [3].

The estimated annual emissions of pollutants in the air from road transport are given in the Table 6.

Table 4. Estimated emissions from waste in the Krapina-Zagorje County in 2011 and 2015

\begin{tabular}{|c|c|c|c|c|c|c|}
\hline \multirow{2}{*}{} & \multicolumn{3}{|c|}{ Waste } & \multicolumn{3}{c|}{ Waste water } \\
\cline { 2 - 8 } & \multicolumn{3}{|c|}{$\mathrm{t} /$ year } \\
\cline { 2 - 7 } & NMVOC & $\mathrm{PM}_{10}$ & $\mathrm{CH}_{4}$ & $\mathrm{CH}_{4}$ & $\mathrm{~N}_{2} \mathrm{O}$ & VOC \\
\hline 2011 & 30.96 & 0.004 & 1472.61 & 523.91 & 9.87 & 0.021 \\
\hline 2015 & 25.71 & 0.004 & 1259.32 & 523.73 & 10.01 & 0.013 \\
\hline
\end{tabular}

Table 5. Number of registered vehicles in the Krapina-Zagorje County and average fuel consumption

\begin{tabular}{|c|c|c|c|c|c|}
\hline \multicolumn{7}{|c|}{ Registered vehicles in Krapina-Zagorje County } \\
\hline & $\begin{array}{c}\text { Passenger } \\
\text { cars }\end{array}$ & LV & HV & Motorcycle & Total \\
\hline 2011 & 44.028 & 51 & 9.978 & 3.928 & 57.985 \\
\hline 2015 & 46.272 & 35 & 10.844 & 3.536 & 60.687 \\
\hline Average annual journey per vehicle on the territory of the Republic \\
of Croatia (km) \\
\hline 2011 & 11908 & 12020 & 13569 & 3006 & \\
\hline 2015 & 11731 & 11831 & 14617 & 2361 & \\
\hline \multicolumn{7}{|c|}{ Average fuel consumption (kg/km) } \\
\hline gasoline & 0.07 & 0.1 & & 0.035 & \\
\hline diesel & 0.06 & 0.08 & 0.24 & \\
\hline
\end{tabular}


Table 6. Total emissions from road transport

\begin{tabular}{|c|c|c|c|c|c|c|c|c|c|}
\hline \multicolumn{10}{|c|}{ t/year } \\
\hline & $\mathrm{CO}$ & $\mathrm{NO}_{\mathrm{x}}$ & $\mathrm{PM}_{10}$ & $\mathrm{CO}_{2}$ & $\mathrm{SO}_{\mathrm{x}}$ & $\mathrm{VOC}$ & $\mathrm{CH}_{4}$ & $\mathrm{~N}_{2} \mathrm{O}$ & $\mathrm{NH}_{3}$ \\
\hline 2011 & 1308.83 & 1180.57 & 32.29 & 210565.44 & 23.49 & 169.79 & 13.29 & 223.00 & 9.99 \\
\hline 2015 & 1028.22 & 1374.14 & 40.08 & 227545.33 & 20.56 & 143.77 & 13.00 & 274.13 & 6.55 \\
\hline
\end{tabular}

\section{Total emissions}

Total estimated pollutant emissions: nitrogen oxides $\left(\mathrm{NO}_{\mathrm{x}}\right)$, carbon monoxide $(\mathrm{CO})$, sulphur oxides $\left(\mathrm{SO}_{\mathrm{x}}\right)$, non-methane volatile organic compounds (NMVOC), particles $\mathrm{PM}_{10}$, ammonia $\left(\mathrm{NH}_{3}\right)$, and greenhouse gases: carbon dioxide $\left(\mathrm{CO}_{2}\right)$, methane $\left(\mathrm{CH}_{4}\right)$ and dinitrogen monoxide $\left(\mathrm{N}_{2} \mathrm{O}\right)$ in Krapina-Zagorje County in 2015 are presented in Figures 1 - 9.

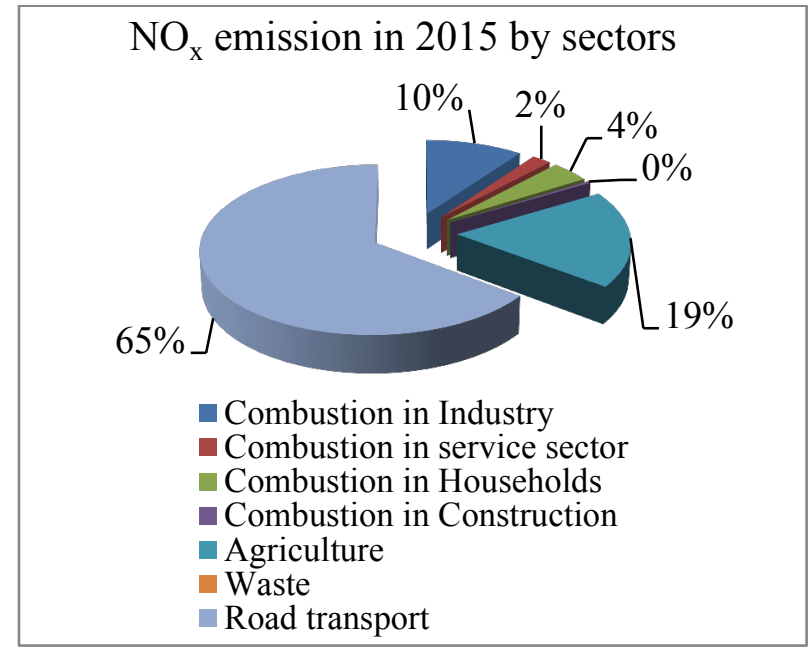

Figure 1. Estimated emission of $\mathrm{NO}_{\mathrm{x}}$ by sectors in 2015

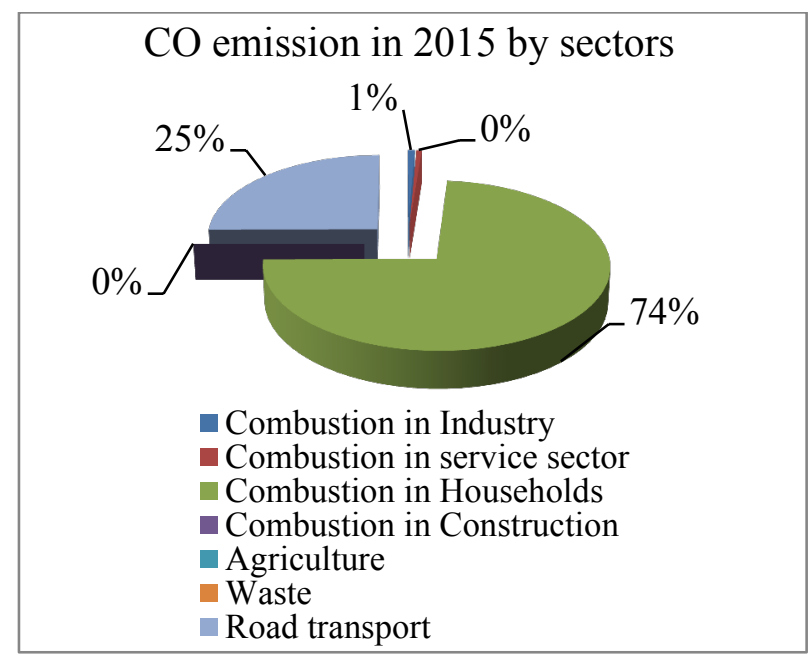

Figure 2. Estimated emission of $\mathrm{CO}$ by sectors in 2015

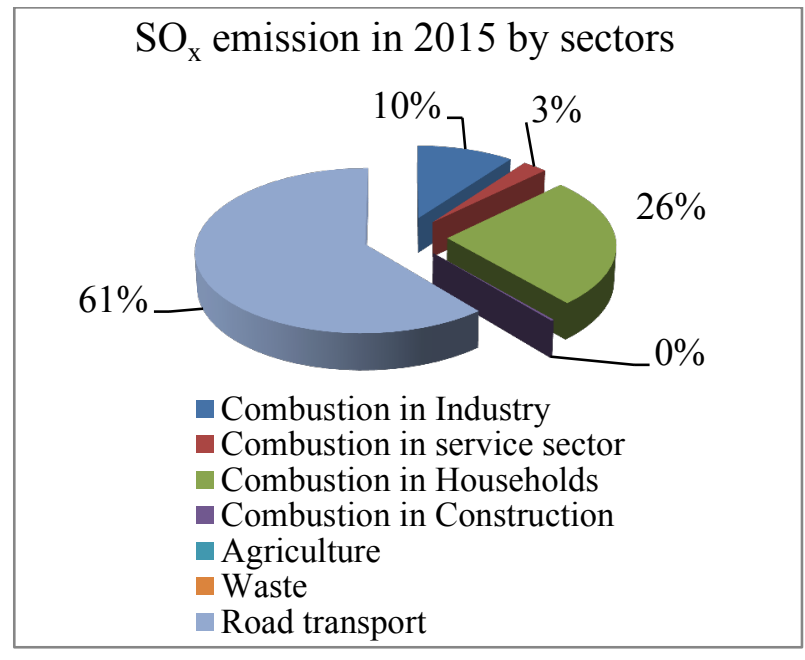

Figure 3. Estimated emission of $\mathrm{SO}_{\mathrm{x}}$ by sectors in 2015

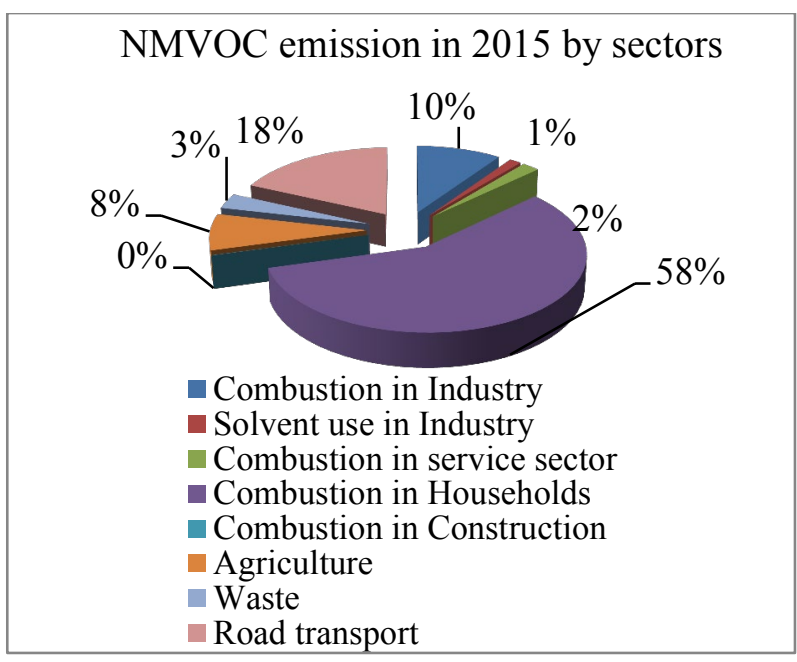

Figure 4. Estimated emission of NMVOC by sectors in 2015 


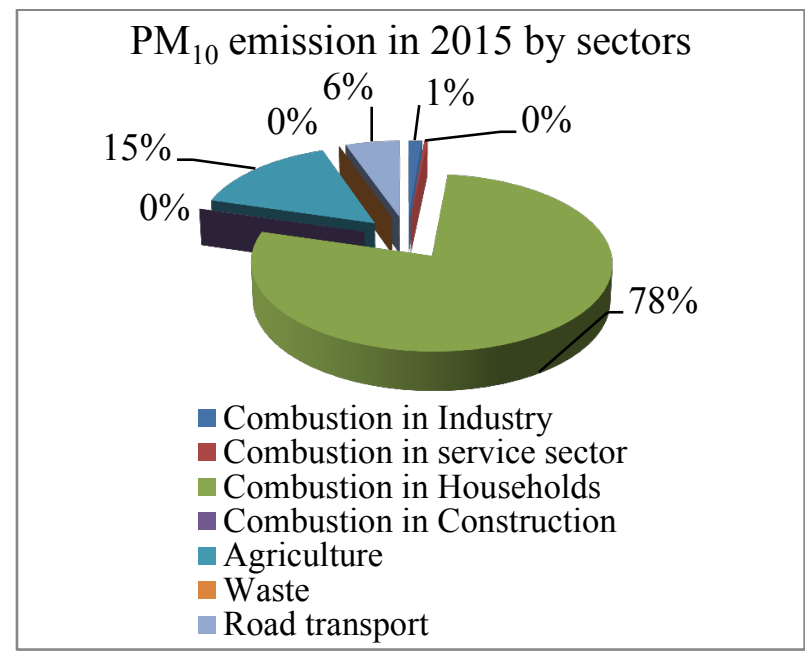

Figure 5. Estimated emission of PM10 by sectors in 2015

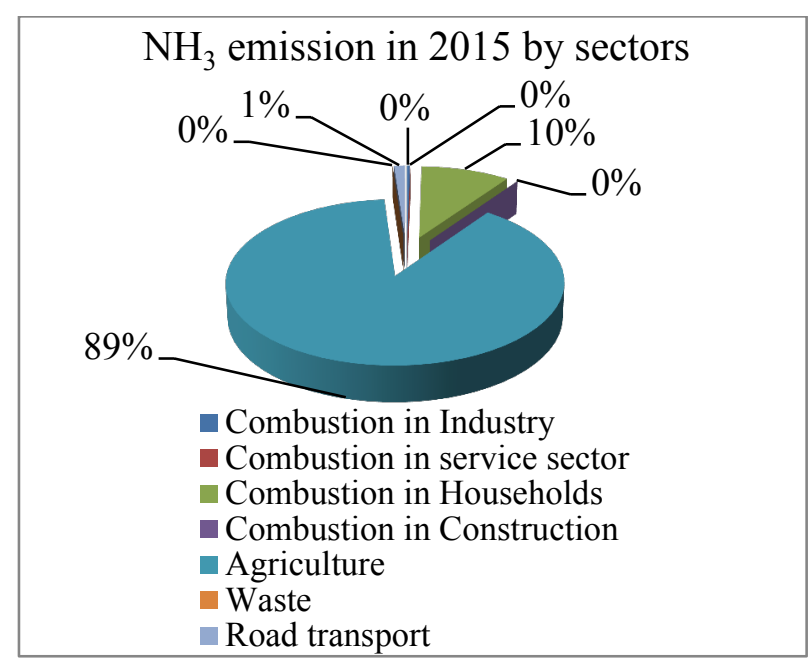

Figure 6. Estimated emission of $\mathrm{NH}_{3}$ by sectors in 2015

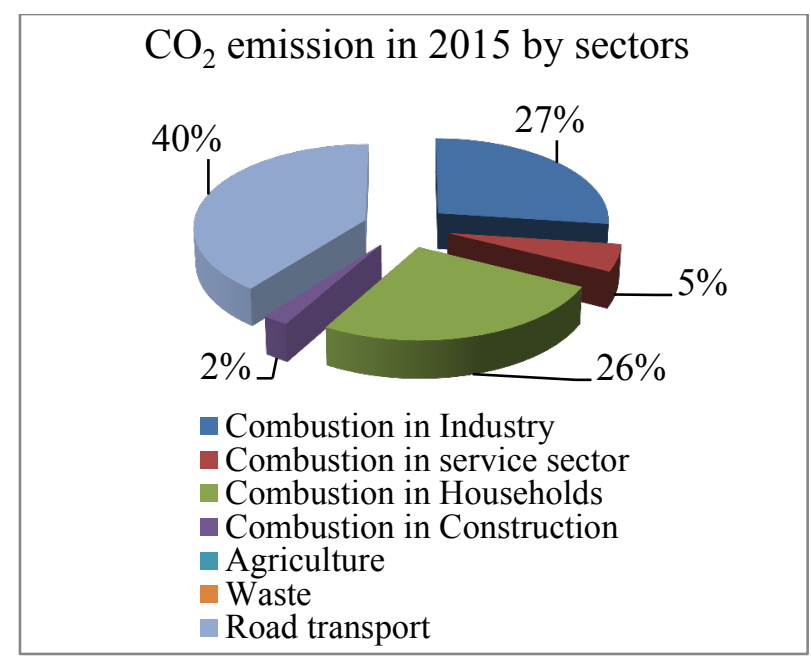

Figure 7. Estimated emission of $\mathrm{CO}_{2}$ by sectors in 2015

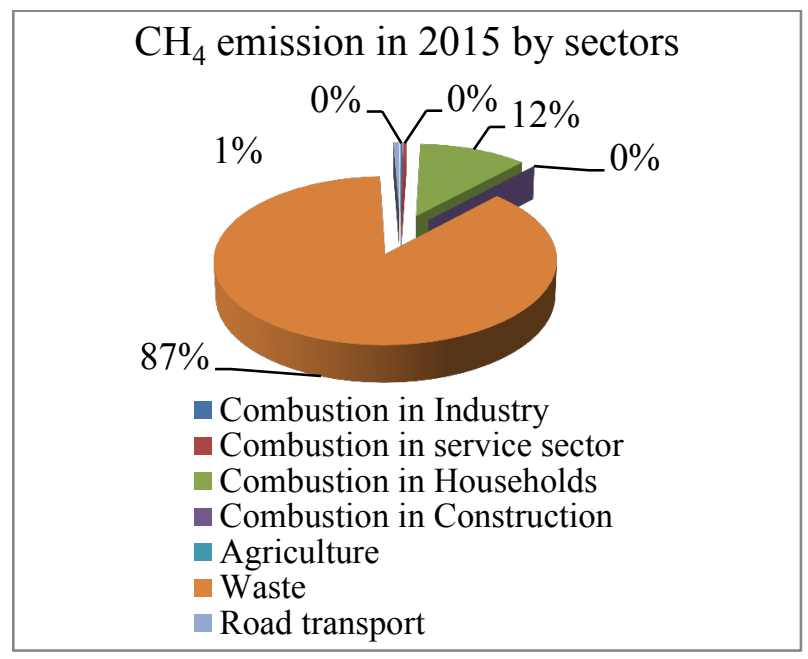

Figure 8. Estimated emission of $\mathrm{CH}_{4}$ by sectors in 2015

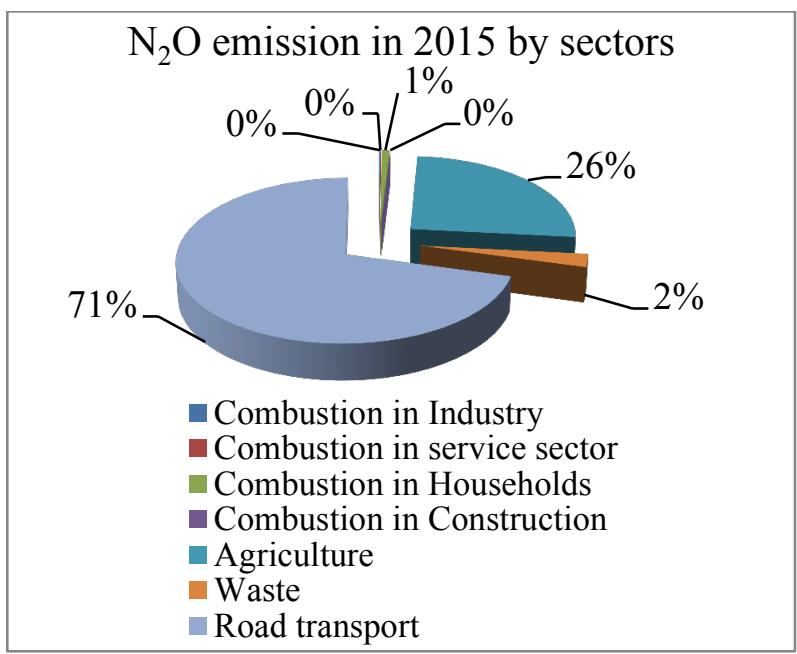

Figure 9. Estimated emission of $\mathrm{N}_{2} \mathrm{O}$ by sectors in 2015

The data in Figures 1 - 9 shows that Energy sector (combustion of fuel in stationary sources and in road transport) is the main source of emission of pollutants into the air in the Krapina-Zagorje County. Road transport is the largest source of nitrogen oxides $(65 \%$ of total emissions) (Figure 1) and sulphur oxides $(61 \%)$ (Figure 3 ) and is an equally important source of carbon monoxide (25\%) (Figure 2) and carbon dioxide (40 \%) (Figure 7). Combustion in households is the largest source of $\mathrm{PM}_{10}(78 \%)$ (Figure 5), carbon monoxide (74\%) (Figure 2), VOC (58\%) (Figure 4) and a significant source of carbon dioxide $(26 \%)$ (Figure 7). As can be seen in Table 1, VOC and $\mathrm{PM}_{10}$ emissions from households originate primarily from combustion of fuel wood 
(biomass) and natural gas is most often used as a fuel.

Disposal of waste and wastewater is a significant source of methane emissions (87 \%) (Figure 8). Agriculture, i.e. the application of mineral fertilizers, is the most important source of ammonia $\mathrm{NH}_{3}(89 \%)$ (Figure 6), but also nitrogen oxides - $\mathrm{NO}_{\mathrm{x}}$ (19\%) (Figure 1) and $\mathrm{N}_{2} \mathrm{O}(26 \%)$ (Figure 9) emissions.

\section{CONCLUSION}

For the purpose of defining appropriate protection and improving air quality in the area of Krapina-Zagorje County, estimation of emissions of main pollutant was performed. Given limited data availability Tier 1 methodology was mostly used. Taking into account that some emissions were not included next conclusion is given.

In the year 2015 estimated emissions of pollutants increased in relation to 2011 in the energy sector and to a smaller decrease in other sectors (industry, waste and agriculture) and overall emissions given the largest contribution of the energy sector, grew.

The largest source of nitrogen oxides is road transport. Combustion in households is the largest source of $\mathrm{PM}_{10}$. VOC emissions from households originate primarily from combustion of wood (biomass) which, together with natural gas, is most often used as a fuel.

Disposal of waste and wastewater are significant sources of methane emissions while the application of mineral fertilizers in agriculture is the most important source of ammonia $\mathrm{NH}_{3}$.

These estimated emissions were used as a basis for defining measures for the realization of the main objective of the protection of air quality and protection and improvement of the quality of life in the Krapina-Zagorje County.

\section{REFERENCES}

[1] Air Protection Act (Official Gazette 130/11, 47/14, 61/17, 118/18).

https://www.zakon.hr/z/269/Zakon-oza\%C5\%A1titi-zraka

Accessed: December 15, 2018.

[2] Program energetske učinkovitosti u neposrednoj potrošnji energije Krapinsko-zagorske županije 2014 2016. godine, REGEA, 2014. http://www.kzz.hr/str.aspx? content id $=p$ rogram-plan-energetske-ucinkovitosti2014-2016\&category id=energetskaucinkovitost\&ispis $=$ DA

Accessed: December 15, 2018.

[3] EMEP/EEA air pollutant emission inventory guidebook 2016 Technical guidance to prepare national emission inventories. European Environment Agency, 2016.

https://www.eea.europa.eu/publications/ emep-eea-guidebook-2016

Accessed: December 15, 2018.

[4] 2006 IPCC Guidelines for National Greenhouse Gas Inventories.

https://www.ipcc-

nggip.iges.or.jp/public/2006gl/

Accessed: December 15, 2018.

[5] Baza podataka "Emisije hlapivih organskih spojeva", HAOP.

http://www.haop.hr/hr/baze-iportali/hlapivi-organski-spojevi

Accessed: December 15, 2018.

[6] EIB European Investment Bank Induced GHG Footprint. Methodologies for the Assessment of Project GHG Emissions and emission Variations. Version 10.1.2014.

https://www.eib.org/en/about/documents /footprint-methodologies.htm

Accessed: December 15, 2018.

[7] Greenhouse Gas Inventory Report for the Republic of Croatia for the Period 1990 - 2014, NIR 2016, HAOP.

www.haop.hr/sites/default/files/uploads/ dokumenti/012 klima/.../NIR 2016.pdf Accessed: December 15, 2018.

[8] DEFRA/DECC (Department for Environmental. Food \& Rural Affairs / 
Department of Energy \& Climate Accessed: December 15, 2018.

Change - UK).

https://www.gov.uk/government/organis

ations

Accessed: December 15, 2018.

[9] Regulations on emission limit values for air emissions from stationary sources (Official Gazette 87/17).

https://narodnenovine.nn.hr/clanci/sluzbeni/2017 $08 \quad 8$ 7 2073.html

Accessed: December 15, 2018.

[10] Izvješće o komunalnom otpadu za 2011. godinu, HAOP.

http://www.haop.hr/sites/default/files/upl oads/dokumenti/021 otpad/Projekti/OTP PR_IPA\%20DCP14\%20Izvjesce \%20k omunalni\%20otpad\%202011.pdf

Accessed: December 15, 2018.

[11] Izvješće o komunalnom otpadu za 2015. godinu, HAOP.

www.haop.hr/.../komunalni/OTP Izvješć e\%20o\%20komunalnom\%20otpadu_201 $\underline{5 . . p d f}$

Accessed: December 15, 2018.

[12] Popis stanovništva 2011, Central Bureau of Statistics of the Republic of Croatia. https://www.dzs.hr/hrv/censuses/census2 011/censuslogo.htm Accessed: December 15, 2018.

[13] Environmental Pollution Register Database, 2011 and 2015. https://www.eea.europa.eu/data-andmaps/data/member-states-reporting-art7-under-the-european-pollutant-releaseand-transfer-register-e-prtr-regulation-21 Accessed: December 15, 2018.

[14] Ministry of the Interior Affairs of the Republic of Croatia, data submitted on request.

[15] Statistički ljetopis 2011, Central Bureau of Statistics of the Republic of Croatia, Zagreb 2011.

https://www.dzs.hr/Hrv_Eng/ljetopis/20 11/SLJH2011.pdf

Accessed: December 15, 2018.

[16] Statistički ljetopis 2015, Central Bureau of Statistics of the Republic of Croatia, Zagreb 2015.

www.dzs.hr/Hrv Eng/ljetopis/2015/sljh2 $\underline{015 . p d f}$ 